UDC 62-531.7

I. Sydorenko, DSc, Prof.,

I. Prokopovych, DSc, Prof.,

M. Korolkova,

S. Dmitrieva,

S. Kovban

Odessa National Polytechnic University, 1 Shevchenko Ave, Odessa, Ukraine,65044; e-mail: igs.ods@gmail.com

\title{
PERFORMANCE CHARACTERISTICS OF THE LEVER-VAN SHOCK ABSORBER WITH THE HINGE-LEVER CONTROL MECHANISM
}

\begin{abstract}
І.І. Сидоренко, І.В. Прокопович, М.В. Королькова, С.Ю. Дмитрієва, С.В. Ковбан. Робочі характеристики важільнолопатевого амортизатора $з$ шарнірно-важільним механізмом управління. У статті представлений принципово новий зразок пасивного важільно-лопатевого амортизатора 3 шарнірно важільним механізмом управління його робочої характеристикою, застосування якого $є$ ефективним в складі торсіонної підвіски гусеничного транспортного засобу. Ефективність представленого пристрою значно підвищена шляхом науково обгрунтованого розширення його механічної структури додатковою керуючою механічною структурою у вигляді шарнірно-важільного механізму. Наведена розроблена розрахункова схема і відповідна до неї узагальнена математична модель запропонованого пристрою. На базі розробленої узагальненої математичної моделі проведені аналітичні дослідження, на основі яких отримані математичні вирази. що описують функціональну взаємодію між складовими елементами запропонованого важільно-лопатевого амортизатора і показаний їх вплив на вигляд робочих характеристик, що при цьому реалізуються. Проведено порівняльний аналіз отриманих робочих характеристик з робочими характеристиками, які можуть бути реалізовані за допомогою існуючих важільно-лопатевих амортизаторів. Встановлено, що запропонований пристрій здатний реалізувати робочі характеристики, які неможливо реалізувати за допомогою відомих зразків пасивних важільно-лопатевих і важільно-поршневих амортизаторів. Виділено та обгрунтовано основні геометричні параметри як основної механічної структури запропонованого пристрою, так і додаткової механічної структури управління, варіація якими дозволяє відтворити цільові (потрібні при деяких умовах) робочі характеристики. Наведено напрямки і перспективи подальших досліджень, що дозволяють підвищити ефективність важільно-лопатевого амортизатора $з$ шарнірно - важільним механізмом управління.

Ключові слова: важільно-лопатевий амортизатор, торсійна почіпка, механізм керування, робочі діаграми, робочі характеристики

I. Sidorenko, I. Prokopovych, M. Korolkova, S. Dmitrieva, S. Kovban. Performance characteristics of the lever-van shock absorber with the hinge-lever control mechanism. The article presents a fundamentally new example of a passive lever-blade shock absorber with an articulated lever mechanism for controlling its operating characteristic, the use of which is effective as part of the torsion bar suspension of a tracked vehicle. The efficiency of the presented device is significantly increased by scientifically substantiated expansion of its mechanical structure with an additional controlling mechanical structure in the form of a pivot-lever mechanism. The developed structural scheme and the corresponding generalized mathematical model of the proposed device are presented. Based on the developed generalized mathematical model, analytical studies have been carried out, on the basis of which mathematical expressions have been obtained that describe the functional interaction between the constituent elements of the proposed lever-blade damper and their influence on the type of working characteristics that is realized in this case. A comparative analysis of the obtained performance with the performance that can be implemented using existing leverblade shock absorbers is carried out. It was found that the proposed device is able to realize working characteristics that cannot be realized using known samples of passive lever-blade and lever-piston shock absorbers. The basic geometric parameters of both the main mechanical structure of the proposed device and the additional mechanical control structure, the variation of which allows reproducing the target (needed under certain conditions) working characteristics, are highlighted and substantiated. The directions and prospects of further research are given, which make it possible to increase the efficiency of the lever-paddle shock absorber with the articulated-lever control mechanism.

Keywords: lever-paddle shock absorber, torsion bar suspension, control mechanism, working diagrams, performance characteristics
\end{abstract}

\section{Introduction}

To date, the use of a shock absorber with translational or rotational movement of the working link in the drive of the engine can not fully take into account the specifics of the use of the link. Piston shock absorbers of various schemes, which are axial devices with translational movement of the working link, are widely used in tracked engines with torsion hitch $[1,2,3]$. The use of piston shock absorbers in the torsion suspension is irrational, because in this type of suspension the angular displacement relative to the body of the balancer is determined. First of all, it can be considered irrational to 
attach the body of the piston shock absorber and its rod (working link) to the body of the machine and the balancer $[2,4]$ by means of ball joints. This solution is necessary due to the design features and the principle of operation of the piston shock absorber, which does not provide for the action of bending moments on its rod. Similarly, this leads to the following problem. Fastening of the piston shockabsorber to the car body by means of ball joints leads to constant change of the system of external forces operating on the shock-absorber as in this case the cylinder and a shock-absorber rod in the course of work constantly change the position concerning the engine case. In this case, the real picture of the shock absorber load may differ significantly from the calculation schemes, according to which its performance is determined.

The use of shock absorbers, the body of which is directly attached to the body of the engine, will be more natural for the suspension, the elements of which carry out angular movements. Such devices include lever-piston and lever-vane shock absorbers (LPA and LVA) [5, 6, 7]. Given the relative simplicity of the design of LVA in comparison with LPA, their use in the composition of torsion hooks can be considered more preferable (Fig. 1).
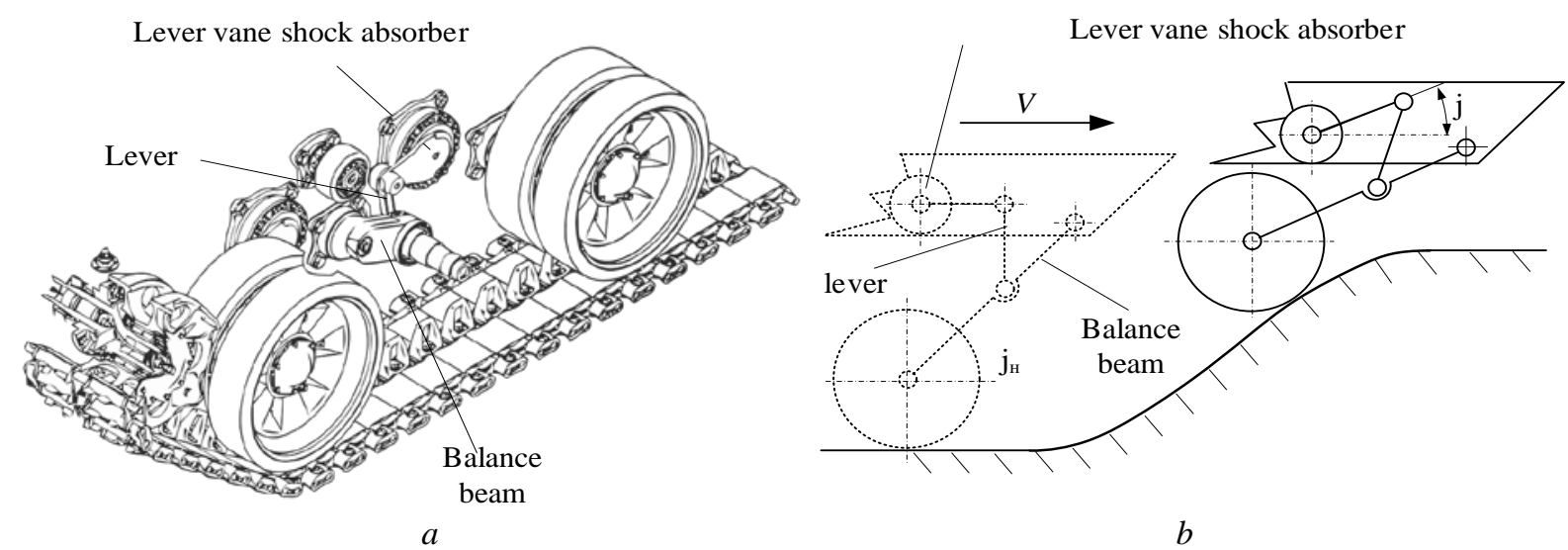

Fig. 1. Lever-vane shock absorber: use as part of a caterpillar propulsion (a); scheme of work at overcoming of an obstacle $(b)$

To confirm the advantage of the use of LVA and LPA in the torsion suspensions of machines operating in severe conditions, it was found that the operating temperature of the LVA (for example, in the case of use in the suspension of products T-72 and T-62) is lower than the same conditions of piston shock absorbers (for example, on the product T-80) [4, 8]. This is explained by the fact that the body of the LVA structurally provides a tight contact with the massive board of the machine, which provides greater heat transfer $[4,8,9]$. The housings of axial piston shock absorbers, due to their design features, can not provide such contact and, as a consequence, their housings are forced to supplement the cooling fins. The effectiveness of such solutions, given the operating conditions of the shock absorbers (dirt accumulation, etc.), is questionable.

However, the performance of existing LVAs cannot fully meet the existing requirements for smooth running of caterpillar propulsion. This problem is the main reason for the use of axial piston shock absorbers in the composition of torsion suspensions, because their performance is more in line with modern requirements. In addition, the technology of manufacturing piston shock absorbers, which determines their relatively low cost and ensures their widespread use is well established [5, 7, 8, 10]. Based on the above, it is necessary to consider relevant scientific and applied problem of synthesis and analysis of a fundamentally new lever-vane shock absorber. It will be designed to work as part of torsion suspensions of tracked engines. And its performance will exceed the performance of both existing axial piston shock absorbers and known lever-piston and lever-vane shock absorbers.

\section{Analysis of recent achievements and publications, problem statement}

Research related to the application of the technique of modified kinematic graphs for structural analysis and synthesis of elastic and dissipative mechanisms have shown that by adding to the structures 
of existing mechanisms of additional mechanical structures, you can significantly expand their functionality $[11,12,13]$.

The result of the application of this technique for structural analysis and subsequent structural synthesis of this device is a fundamentally new design of LVA [14]. The structural analysis of one of the existing LVA with a throttle hole of constant cross section allowed to obtain the basic structure, which became the basis of structural synthesis $[3,6]$. The result of the synthesis is a device whose structure is supplemented by a mechanical control structure in the form of a hinged-lever mechanism (Fig. 2). The shock-absorber consists of the case 1 in which cylindrical boring membranes 2 with a rectangular throttle opening are radially established. Shaft 3 with blades is installed coaxially in the cylindrical bore of the housing. The side washers 4 and flange covers with bearings 5 serve to orient the shaft 3 and create an internal sealed cavity. In this LVA additional mechanical

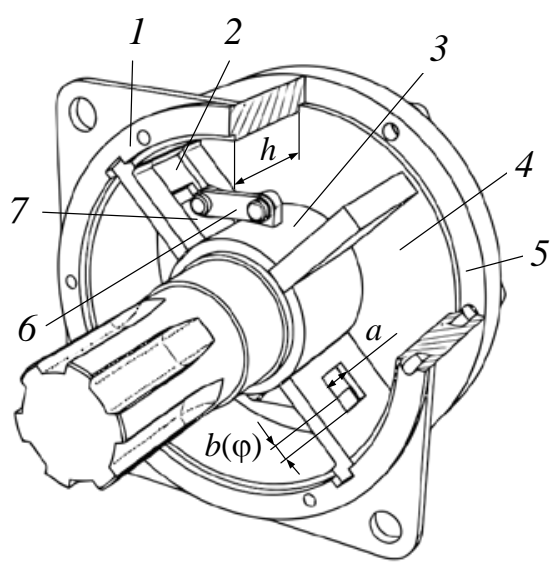

Fig. 2. Lever-vane shock absorber with hinged-lever mechanism structure, in the form of a hinge-lever mechanism, is represented by a lever 6 and a slider 7 . One end of the lever is hinged to the shaft 3 , and the other on the slider 7 . The slider 4, moving in the radial direction along the membrane 2 , may partially or completely cover the throttle hole. The presence of this mechanical structure significantly changes the performance of the shock absorber, as it determines the mechanical feedback between the amount of displacement of the working body of the shock absorber and the area of the throttle hole.

There is a problem of determining the performance for a fundamentally new lever-vane shock absorber with a hinged-lever control mechanism. It remains unresolved to determine the relationship between the presence of the control mechanism with the main design parameters of the proposed device.

The purpose of the research is to create a calculation scheme and calculation of performance characteristics that can be implemented by the proposed lever-vane shock absorber with a hinged-lever control mechanism to determine its functionality.

Presentation of the main material of the study with a full justification of the obtained scientific results

During theoretical research, a lever-vane shock absorber with an additional mechanical structure was considered. When compiling the calculation schemes, the numbering of the scheme of the device of its main elements is preserved (Fig. 2).

Assume that at the initial time the angle between the blades of the shaft 3 and the jumpers 2 is 90 (Fig. 3). Consider the process of compression, when an external load is applied to the shaft in the form of torque $\mathrm{M}$ and the working fluid flows from the working cavity I into the cavity II through the throttle hole in the membrane.

The volume of which is described by the blade of the object per unit time (flow) is equal to the volumetric flow rate of the liquid flowing through the throttle hole:

$$
Q_{l}=Q_{o} .
$$

The volume that describes the blade of a given object per unit time is calculated as the product of the speed of movement of the blade $\omega$ on its area:

$$
Q_{p}=\frac{\pi\left(r_{1}^{2}-r_{2}^{2}\right) h}{2 \pi} \cdot \frac{\mathrm{d} \varphi}{\mathrm{d} t}=\frac{\left(r_{1}^{2}-r_{2}^{2}\right) h}{2} \omega,
$$

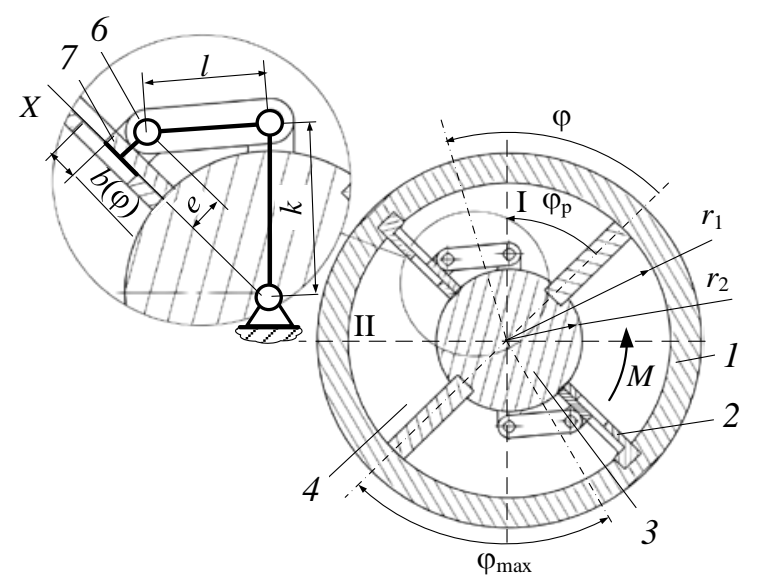

Fig. 3. The design scheme of the proposed lever-vane shock absorber 
where $r_{1}$ - the radius of the inner cylindrical surface of the shock absorber housing,

$r_{2}$ - the radius of the outer surface of the shaft;

$h$ - housing width;

$\varphi$ - the angle of rotation of the shaft with blades relative to the body with membranes;

$\omega$ - turning speed.

The volumetric flow rate of the fluid flowing through the throttle hole of the membrane, taking into account its area, calculated by the Torricelli formula:

$$
Q_{o}=2 \mu A_{o} \sqrt{2 \frac{p_{1}}{\rho}},
$$

where $\mu$-flow rate ( $\mu=0.85$ for a rectangular hole with the number $\operatorname{Re}<10000$ [4]);

$A_{\mathrm{o}}$ - the area of the rectangular throttle hole;

$\rho$ - the density of the working fluid (machine oil $\rho=0.9 \cdot 10^{3} \mathrm{~kg} \backslash \mathrm{m}^{3}[5]$ ).

Then, taking into account (3), equation (2) takes the form:

$$
\frac{\left(r_{1}^{2}-r_{2}^{2}\right) h}{2} \omega=2 \mu A_{o} \sqrt{2 \frac{p_{1}}{\rho}},
$$

Solution of equation (4) with respect to pressure $p_{1}$ for this sample:

$$
p_{1}(\omega)=\frac{h^{2} \omega^{2}\left(r_{1}^{4}-2 r_{1}^{2} r_{2}^{2}+r_{2}^{4}\right)}{2(a b)^{2} \mu^{2} \rho}
$$

For this sample, the presence of an additional mechanical structure in the form of a hinge-lever mechanism consisting of a lever 4 and a slider 5, allows you to convert the angular displacement $\varphi$ of the shaft 3 relative to the housing 1 (controlled displacement) in the displacement $b(\varphi)$ of the slider 7 in the radial direction on a membrane 2 of the case 1 (controlled movement).

The slider 5 may partially or completely cover the throttle hole. We will assume that in the initial position the throttle hole is fully open. Suppose that as the angle of rotation of the shaft $\varphi$ increases, it changes, and the change in its area at a constant value of the parameter a depends on the magnitude of the movement of the slider $b(\varphi)$, which, for this design, is determined by:

$$
b(\varphi)=b_{n}-\left[k \cdot \cos (\varphi)+l \cdot \cos \left(\arcsin \left(\frac{k \cdot \sin (\varphi)-e}{l}\right)\right)\right],
$$

where $b_{n}$ - the length of the rectangular throttle hole at the time taken as the initial.

Then, the change in the area of the throttle hole on the membrane 2 depending on the angle of rotation of the shaft $\varphi$ is described by:

$$
A_{o}(\varphi)=a\left(b_{n}-b(\varphi)\right)
$$

When solving equation (5) with respect to pressure $p_{1}$, taking into account the dependence (6) for this sample obtained:

$$
p_{1}(\omega, \varphi)=\frac{h^{2} \omega^{2}\left(r_{1}^{4}-2 r_{1}^{2} r_{2}^{2}+r_{2}^{4}\right)}{2\left(a\left(b_{\mathrm{H}}-b(\varphi)\right)^{2} \mu^{2} \rho\right.}
$$

To determine the performance characteristics of the sample, set the values of its geometric parameters (Table 1). 
Geometrical parameters of the lever-vane shock-absorber with the hinged-lever control mechanism

\begin{tabular}{c|l|c}
\hline$№$ & \multicolumn{1}{|c|}{ Name of the parameter (designation), unit of measurement } & Value \\
\hline 1 & Radius of an internal cylindrical surface of the case of the shock-absorber $\left(r_{1}\right), \mathrm{mm}$ & 60 \\
\hline 2 & Radius of the outer surface of the shaft $\left(r_{2}\right), \mathrm{mm}$ & 20 \\
\hline 3 & Shock absorber housing width $(h), \mathrm{mm}$ & 40 \\
\hline 4 & The maximum angle of rotation of the shaft with the blades relative to the body $\left(\varphi_{\max }\right)$, deg & 75 \\
\hline 5 & Throttle width $(a), \mathrm{mm}$ & 15 \\
\hline 6 & Throttle length $\left(b_{n}\right), \mathrm{mm}$ & 25 \\
\hline 7 & Maximum shaft rotation speed $(\omega), 1 / \mathrm{sec}$. & 0,5 \\
\hline 8 & The distance from the axis of the device to the place of attachment of the lever on the shaft $(k), \mathrm{mm}$ & 25 \\
\hline 9 & The length of the lever $(l)$, mm & 20 \\
\hline 10 & The distance from the membrane to the place of attachment of the lever on the slider $(e)$, mm & 5 \\
\hline
\end{tabular}

It should be noted that the type of performance of the shock absorber is influenced by the magnitude and law of change of speed of its moving element. Assume that the crawler hits an obstacle that determines the full stroke in the form of a sinusoid, and the change in speed of the shock absorber shaft occurs within $t=2$ seconds, according to the expressions:

$$
\omega=0.5 t \text { at } 0 \leq t \leq 1 \text { and } \omega=1-0.5 \mathrm{t} \text { at } 1 \leq t \leq 2 \text {. }
$$

In order to simplify the mathematical calculations in solving equation (8), the expression included in it (7) and taking into account the accepted values of the geometric parameters of the samples, it is advisable to replace the corresponding power polynomial:

$$
b(\varphi)=0.0057 \varphi^{3}+0.0111 \varphi^{2}+0.0443 \varphi+0.00001 ; \quad R^{2}=1 .
$$

Then the solution of equation (7) with respect to pressure takes the final form:

$$
p_{1}(\omega, \varphi)=\frac{2.4885 \cdot 10^{62} \omega^{2}}{\left(570 \cdot \varphi^{3}+1110 \cdot \varphi^{2}-4430 \cdot \varphi+3001\right)^{2}} .
$$

For the considered sample the graphic interpretation of definition of working characteristic shows the following. Calculations by expression (8), which determines the pressure in the working cavity of the shock absorber at different values of the speed of movement of the working link, allows to obtain a family of asymmetric working diagrams for this sample (Fig. 4, a). The received working diagrams in this case testify that pressure depends not only on speed of movement of a working link, but also on its position in the range of a working course. Therefore, given the close relationship between the parameters of velocity-displacement, when constructing the operating characteristics of the sample must take into account not only the law of velocity (Fig. $4, b$ ), but also the law of displacement associated with the time parameter $\mathrm{t}$ (Fig. 4, c). Given that the working diagrams of the sample in this case are asymmetric about the middle of the working stroke, the working characteristic is a loop (Fig. 4, $d$ ). The lower part of the loop, which is bounded by points $0,1,2,3,4,5$, defines the progressive (throttle) section. It is characterized by a relatively small change in pressure with increasing speed of the working body of the shock absorber in the first half of the stroke. The upper part of the loop, which is bounded by points $5,6,7,8,9$, 0 , defines the degressive (valve) area. It is characterized by high pressures with decreasing speed in the second half of the stroke. This type of performance is not described in the literature, because it is not implemented in the known designs of shock absorbers. 


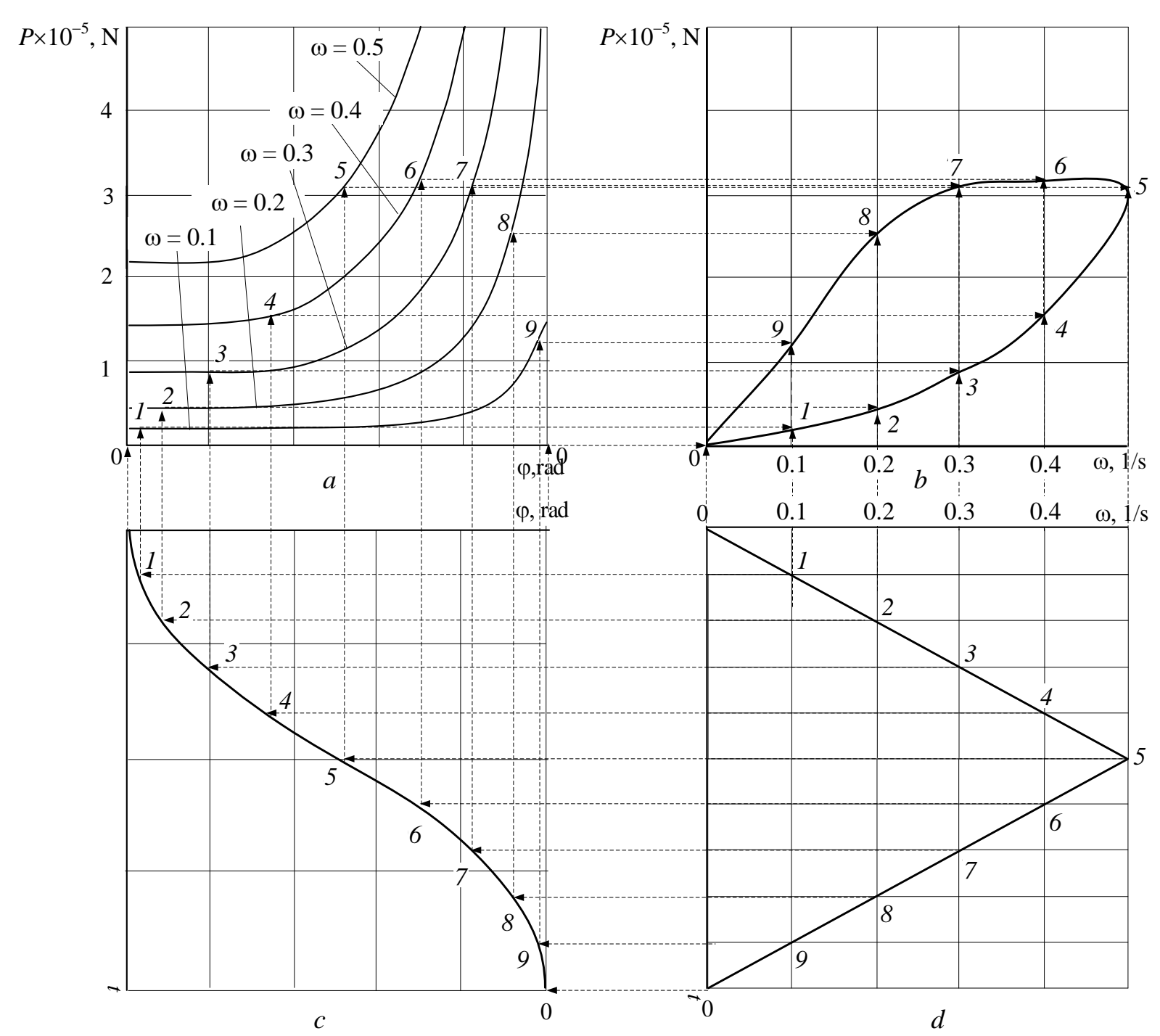

Fig. 4. Construction of the operating characteristics of the lever-vane shock absorber: working diagrams (a); the law of change of speed $(b)$; the law of change of movement $(c)$; performance $(d)$

The calculation, provided that in the process of increasing the angle of rotation of the shock absorber shaft, the throttle hole will open, with other constant parameters allows you to get the performance in the form of a loop (Fig. 5, a).

The initial section of the characteristic will correspond to the upper part of the loop, which is bounded by points $0,1,2,3,4,5$, which defines the degressive (valve) section. In this case, it is characterized by large changes in pressure with increasing speed of the working body of the shock absorber in the first half of the stroke.

The lower part of the loop, bounded by points $5,6,7,8,9,0$, defines the progressive (throttle) section. It is characterized by high pressures with decreasing speed in the second half of the stroke. This performance is also not implemented in the known designs of shock absorbers.

From a number of calculations it follows that the design of the sample has several main design parameters that determine its performance. These include the shape, size, number and location of the throttle holes on the membrane, as well as the length of the lever 6 , the shape and size of the slider 7 (see Fig. 3). 
$a$
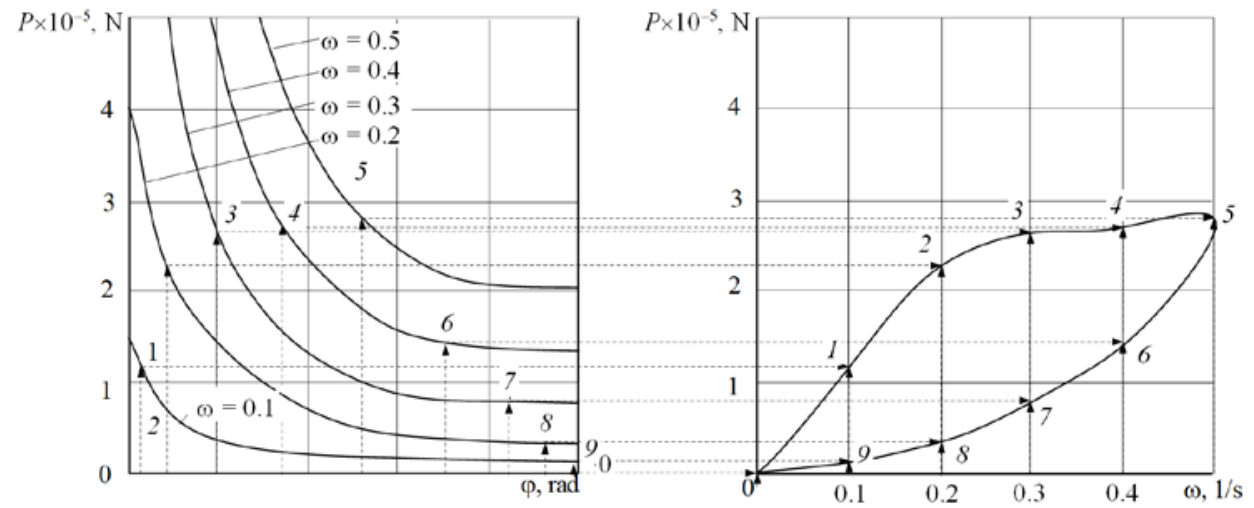

$b$
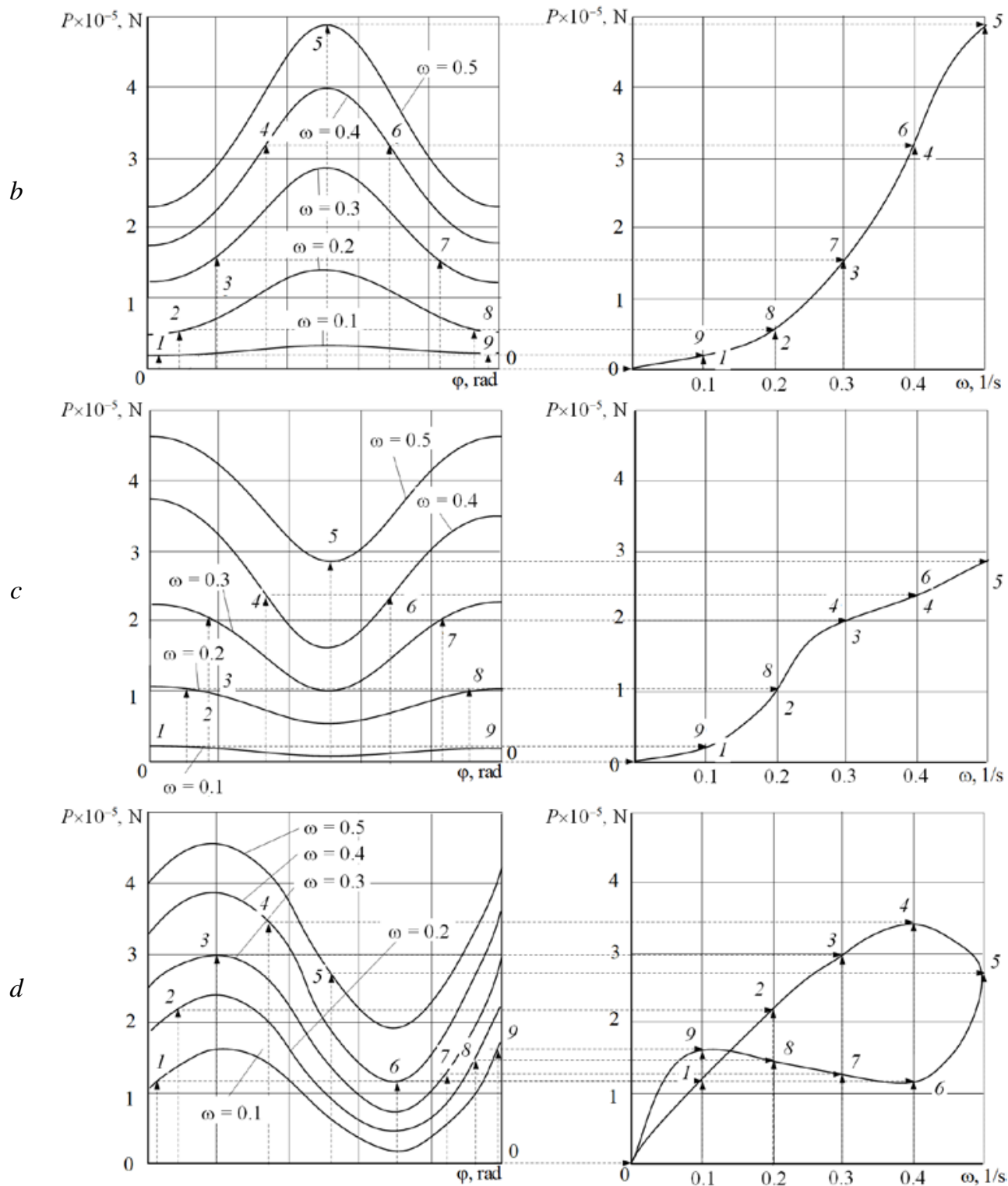

Fig. 5. Operating diagrams and characteristics: when reducing the throttle hole in the magnitude of the working stroke $(a)$; when reducing the throttle hole by 0.5 stroke $(b)$; when increasing the throttle hole by 0.5 stroke $(c)$; when reducing the throttle hole by 0.25 stroke, followed by an increase of 0.75 stroke $(d)$ 
With different variations of these parameters, the considered sample allows to implement different types of performance characteristics, both symmetrical (Fig. 5, b, Fig. 5, $c$ ) and asymmetrical (Fig. 5, $d$ ).

Moreover, in our opinion, of particular interest may be the performance characteristics that determine the different types of dissipation in certain parts of the stroke, because in this case there are prerequisites for solving such a well-known problem as the "breakdown" of the shock absorber. Assume that the functionality of the proposed shock absorber can be significantly expanded by using curved throttle holes.

\section{Conclusions}

Based on the results of the research, the following was established:

1. Expansion of the main structure of the lever-vane shock absorber with an additional control mechanical structure in the form of a hinged-lever mechanism significantly expands its functionality to implement different performance characteristics.

2. The proposed device will implement both traditional symmetrical characteristics (throttle hole decreases in the middle of the stroke) and performance characteristics that can not be obtained with the help of existing passive shock absorbers.

3. Of particular interest may be implemented by the proposed device performance characteristics that determine the different types of dissipation in certain areas of the stroke.

\section{Prospects for further research}

Based on the fact that the proposed design allows to implement a wide range of performance characteristics of different types of nonlinearity, we can assume the possibility of synthesizing the target performance and the implementation of the optimal performance of the suspension system for the caterpillar mover.

\section{Література}

1. Дущенко В.В., Агапов О.Н. Особливості розрахунку торсіонної підвіски транспортних засобів. Вісник НТУ «ХПІ». Серія: Автомобіле- та тракторобудування. 2014. № 10 (1053). С. 111-120.

2. Дущенко В.В. Питання удосконалення методології аналізу та синтезу систем підресорювання військових гусеничних і колісних машин. Військово-технічний збірник. 2012. № 1. С. $26-32$.

3. Анісімов В.Ф., Зегер М.С. Удосконалення гідросистеми ходової частини гусеничних тракторів. Вісник Вінницького політехнічного інституту. 2011. № 1. С. 129-134.

4. Дмитриев А.А., Чобиток В.А., Тельминов А.В. Теория и расчёт нелинейных систем подрессоривания гусеничных машин. М. : Машиностроение, 2006. 208 с.

5. Котиев Г.О., Смирнов А.А., Шилкин В.П. Исследование рабочих процессов в пневмогидравлических устройствах систем подрессоривания гусеничных машин. М. : Изд-во МГТУ им. Н.Э. Баумана, 2001. 80 с.

6. Острецов А.В., Устименко А.С. Оценка эффективности работы амортизаторов на автомобиле. Грузовик \&. 2012. № 11.

7. Елисеев С.В., Ковыршин С.В., Паршута Е.А. Некоторые вопросы теории виброизоляции. Обоснование структурных подходов. Математическое моделирование, системный анализ. 2013. № 3(89). С. 121-127.

8. Узунов О.В., Ночніченко І.В., Галецький О.С. Уточнення коефіцієнту витрати для гідравлічних дроселів клапанно-дросельних груп. Вісник НТУУ «КПІ». Серія машинобудування. 2014. № 3. C. 169-174.

9. D’Alessandro V., Montelpare S., Ricci R., Zoppia A. Fluid-dynamic analysis of a multi-blade gravity damper. International Journal of Mechanical Sciences. 2018. Vol. 135. P. 14-22.

10. Michalowski B., Rybak P., Wysocki J. Numerical and experimental tests of suspension elements. AIP Conference Proceedings. 04 march 2019. Vol. 2078.

11. Сидоренко И. Пассивные виброизолирующие устройства с элементами активных систем: моногр. Saarbrücken : LAP LAMBERT Academic Publishing GmbH \& Co., 2011. 296 c.

12. Сидоренко I.I. Теоретичне визначення характеристики гідравличного релаксаційного амортизатора з розширеною механічною структурою. Вибрации в технике и технологиях. 2014. № 3(75). C. 94-101. 
13. Сидоренко I.I., Робу C.І., Волков В.П. Робоча діаграма і характеристика гідравлічного релаксаційного амортизатора з розширеною механічною структурою. Автомобильный транспорт. 2014. Вып. 35. С. 60-67.

14. Sydorenk I.I., Zhang Yi Heng. (2015). Synthesis of lever-blade dampers with enhanced mechanical structure. Праці Одеського політехнічного університету. 2015. 1 (45). С. 15-20. DOI: 10.15276/opu.1.45.2015.04.

\section{References}

1. Dushchenko, V.V., \& Agapov, O.N. (2014). Features of calculation of a torsion suspension bracket of vehicles. Bulletin of NTU "KhPI". Series: Car and tractor construction, 10 (1053), 111-120.

2. Dushchenko, V.V. (2012). Issues of improving the methodology of analysis and synthesis of suspension systems of military tracked and wheeled vehicles. Military-technical collection, 1, 26-32.

3. Anisimov, V.F., \& Zeger, M.S. (2011). Improvement of the hydraulic system of the running gear of tracked tractors. Bulletin of Vinnytsia Polytechnic Institute, 1, 129-134.

4. Dmitriev, A.A., Chobitok, V.A., \& Telminov, A.V. (2006). Theory and calculation of nonlinear suspension systems of caterpillar machines. Moscow: Mashinostroenie.

5. Kotiev, G.O., Smirnov, A.A., \& Shilkin, V.P. (2001). Research of work processes in pneumohydraulic devices of crawler vehicle suspension systems. Moscow: Publishing house of MSTU im. N.E.Bauman.

6. Ostretsov, A.V., \& Ustimenko, A.S. (2012). Evaluation of the effectiveness of shock absorbers on a car. Truck \&, 11.

7. Eliseev, S.V., Kovyrshin, S.V., \& Parshuta, E.A. (2013). Some questions of the theory of vibration isolation. Substantiation of structural approaches. Mathematical modeling, system analysis, 3 (89), 121-127.

8. Uzunov, O.V., Nochnichenko, I.V., \& Galetsky, O.S. (2014). Clarification of the flow rate for hydraulic throttles of valve-throttle groups. Bulletin of NTUU “KPI”. Mechanical engineering series, 3, 169-174.

9. D’Alessandro, V., Montelpare, S., Ricci, R., \& Zoppia, A. (2018). Fluid-dynamic analysis of a multiblade gravity damper. International Journal of Mechanical Sciences, 135, 14-22.

10. Michalowski, B., Rybak, P., \& Wysocki, J. (2019). Numerical and experimental tests of suspension elements. AIP Conference Proceedings, 04 march 2019, Vol. 2078.

11. Sidorenko, I. (2011). Passive vibration-isolating devices with elements of active systems: monograph. Saarbrücken: LAP LAMBERT Academic Publishing GmbH \& Co.

12. Sidorenko, I.I. (2014). Theoretical determination of the characteristics of a hydraulic relaxation shock absorber with an extended mechanical structure. Vibrations in engineering and technology, 3 (75), 94-101.

13. Sidorenko, I.I., Robu, S.I., \& Volkov, V.P. (2014). Operating diagram and characteristics of the hydraulic relaxation shock absorber with extended mechanical structure. Road transport, 35, 60-67.

14. Sydorenk, I.I., \& Zhang, Yi Heng. (2015). Synthesis of lever-blade dampers with enhanced mechanical structure. Odes'kyi Politechnichnyi Universytet. Pratsi, 1 (45), 15-20. DOI: 10.15276/opu.1.45.2015.04.

Сидоренко Ігор Іванович; Sydorenko Ihor, ORCID: https://orcid.org/0000-0003-1840-4313

Прокопович Iгор Валентинович; Prokopovych Ihor, ORCID: https://orcid.org/0000-0002-8059-6507

Королькова Марія Василівна; Korolkova Mariya, ORCID: https://orcid.org/0000-0002-3546-6279

Дмітрісва Світлана Юріївна; Dmitrieva Svetlana, ORCID: https://orcid.org/0000-0003-2288-3775

Ковбан Софія Вікторівна; Kovban Sofiia, ORCID: https://orcid.org/0000-0001-9307-7063 